\title{
Health in the school: perceptions of being adolescent
}

\author{
A saúde na escola: percepções do ser adolescente \\ La salud en la escuela: las percepciones del ser adolescente
}

Ligia Cordeiro Matos Faial',II ORCID: 0000-0003-2586-2443

Rose Mary Costa Rosa Andrade Silva' ORCID: 0000-0002-6403-2349

Eliane Ramos Pereira' ORCID:0000-0002-6381-3979

Cidllan Silveira Gomes Faial'," ORCID: 0000-0002-9855-7530

'Universidade Federal Fluminense. Niterói, Rio de Janeiro, Brazil. "Instituto Federal Fluminense. Bom Jesus do Itabapoana, Rio de Janeiro, Brazil.

How to cite this article: Faial LCM, Silva RMCRA, Pereira ER, Faial CSG. Health in the school: perceptions of being adolescent. Rev Bras Enferm. 2020;73(3):e20190068. doi: http://dx.doi.org/10.1590/0034-7167-2019-0068

Corresponding author: Ligia Cordeiro Matos Faial E-mail: licordeiromatos@yahoo.com.br

EDITOR IN CHIEF: Dulce Aparecida Barbosa ASSOCIATE EDITOR: Antonio José de Almeida Filho

Submission: 03-17-2019

Approval: 06-11-2019

\begin{abstract}
Objectives: to understand adolescents' perceptions on school health. Methods: qualitative and descriptive research grounded on Maurice Merleau-Ponty's phenomenology, which was developed with 90 adolescent students from a federal school of the state of Rio de Janeiro. Data were produced by gathering answers to the following question: what is your perception on school health? Those who chose to write their answer to the guiding question deposited the manuscripts in polls. Results: school health is linked to hygienist practices and to the hegemonic assistentialist model. Nevertheless, we assigned senses and meanings to the practice of physical activity and health education by integrating and expanding behavioral strategies and healthy habits. Final Considerations: a healthy school environment implies the protagonism of adolescents in school health promotion actions.

Descriptors: Adolescent; Schools; Health Promotion; Adolescent Health; School Health Services.
\end{abstract}

\section{RESUMO}

Objetivos: compreender as percepções do ser adolescente acerca da saúde na escola. Métodos: pesquisa qualitativa e descritiva apoiada na fenomenologia de Maurice Merleau-Ponty, desenvolvida com 90 alunos adolescentes de uma escola federal do estado do Rio de Janeiro. Os dados foram produzidos pelo discurso falado em resposta ao questionamento: conte para mim qual a sua percepção sobre a saúde na escola. Aqueles que optaram pela resposta escrita à questão norteadora depositaram os manuscritos nas urnas. Resultados: a saúde escolar encontra-se presa às práticas higienistas e ao modelo hegemônico assistencialista. No entanto, sentidos e significados foram atribuídos à prática da atividade física e de educação em saúde - estratégias integradoras e multiplicadoras de comportamentos e hábitos saudáveis. Considerações Finais: o fazer saúde na escola passa pelo protagonismo do ser adolescente sobre sua saúde na reorganização das ações de promoção em saúde escolar.

Descritores: Adolescente; Instituiç̧ões Acadêmicas; Promoção da Saúde; Saúde do Adolescente; Serviços de Saúde Escolar.

\section{RESUMEN}

Objetivos: comprender las percepciones del ser adolescente sobre la salud en la escuela. Métodos: investigación cualitativa, descriptiva, basada en la fenomenología de Maurice Merleau-Ponty, desarrollada con 90 alumnos adolescentes de una escuela federal del estado de Río de Janeiro. Se recogieron los datos por medio del discurso hablado en respuesta al cuestionamiento: ¿cuál es su percepción sobre la salud en la escuela? Aquellos que optaron por escribir la respuesta a esta cuestión principal la depositaron en urnas. Resultados: la salud en la escuela se encuentra vinculada a las prácticas higienistas y al modelo hegemónico asistencialista. Sin embargo, sentidos y significados fueron asignados a la práctica de actividad física y educación en salud -estrategias integradoras y multiplicadoras de comportamientos y hábitos saludables-. Consideraciones Finales: el hacer salud en la escuela pasa por el protagonismo del ser adolescente sobre su salud en la reorganización de las acciones de promoción de la salud en la escuela.

Descriptores: Adolescente; Instituciones Académicas; Promoción de la Salud; Salud del Adolescente; Servicios de Salud Escolar. 


\section{INTRODUCTION}

Adolescence, stage of the life cycle between childhood and adulthood, implies particular biopsychosocial changes to each person, transforming habits and consolidating behaviors. According to the Estatuto da Criança e do Adolescente (ECA) [Brazilian Child and Adolescent Statute], adolescence corresponds to the age group from 12 to 18 years ${ }^{(1)}$, comprising $16.2 \%$ of the Brazilian population - data by the Pesquisa Nacional por Amostra de Domicílios (PNAD) [Brazilian National Research by Household Sample Data] of $2015^{(2)}$. At this stage, adolescents can live new experiences, often with risks regarding perceived vulnerabilities such as the use of drugs and alcohol and violence, which put an end into lives; in addition, many of them also experience precocity of sexual activity, driven by momentary pleasure, disregarding the possibility of pregnancy and contamination and/or spread of sexually transmitted infections $s^{(3)}$. The body as the protagonist of these occurrences assigns experiences and meanings that guide their formation as new human beings in the world ${ }^{(4)}$.

In phenomenology, the body is the subject of perception when it perceives itself as the essence of existence and the locus of the experience from the interaction between man and the world ${ }^{(5)}$; it is a social construct, the core producer of meanings and significations from lived experiences. With the metamorphosis process of adolescence, they acquire a sexualized body as they lose their identity as children. Thus, an individual's body is more than their biological condition, as it is at the core of their perception when experiencing new practices and values, this way assigning significations to each being (6). The adolescent recognizes the school as a favorable environment to develop relationships with others and the world, seeing it as facilitated by value transmission and intellectual formation ${ }^{(7)}$.

In the 2015 PNAD, the schooling rate attributed to a population of 6 to 14 year-olds was of $98.6 \%$, being of $85 \%$ for young people from 15 to 17 years, and of $30.7 \%$ for those from 18 to 24 years, showing potential to develop school health ${ }^{(2)}$. The school is the space where students produce, reproduce and broaden knowledge - requirements that determine the individual's social, cultural and political formation. Adolescents see it as an proper environment to create bonds and to interact with their peers, and also to develop health practices, which demand for further public policies associated with health ${ }^{(7)}$.

To elaborate public policies, the World Health Organization (WHO) recommends the creation of a surveillance system of risk factors related to adolescents' health, such as the Global School Based Student Health Survey (GSHS) ${ }^{(8)}$, the Health Behavior in School-Aged Children (HBSC) ${ }^{(9)}$ and the Youth Risk Behavior Surveillance System ${ }^{(10)}$. In Brazil, we highlight the drafting of the 2004 Pesquisa Nacional de Saúde dos Escolares (PeNSE) [Brazilian National School Health Survey] to map the risk and protection factors of chronic diseases to the health of adolescents, held in 2009, 2012 and 2015. These studies identify the priorities in the developing of public policies on adolescents' health ${ }^{(11)}$; however, they do not to contemplate the demands raised by adolescents themselves.

This study supports the definition of school health based on the Health Science descriptor, understanding it as the "actions directed to the school community to implement health promotion proposals. [...] developing actions to prevent diseases and to strengthen protection factors" ${ }^{\prime \prime 2}$. Nevertheless, this study aims at gathering the perceptions of adolescents on the health service provided at school, from a Merleau-Pontian's perspective.

\section{OBJECTIVES}

To understand the perception of adolescents on school health to subsidize adolescent care in the school setting.

\section{METHODS}

\section{Ethical aspects}

According to resolution No. 466/12 (13), this study was approved by the Research Ethics Committee of the Universidade Federal Fluminense (UFF). The use of the letter A, which stands for "adolescent", followed by a random number ensured the anonymity of the participants interviewed. With this in mind, participants who opted for writing their answers to the guiding question had their manuscripts identified with the letter " $U$ ", which stands for "urn", followed by the number that corresponded to the following distribution of collection urns within school dependencies: U1 (space), U2 (library) and U3 (school yard/photocopies).

The data collection on the understanding of the meaning and signification of school health was authorized by adolescent students who had already came of age and could sign the written Informed Consent Form, or whose parents needed to sign it as their under age children could not do it by themselves, and by under age adolescents who signed the Free and Clarified Consent Term.

In the written reports, without the limitations imposed by shyness and insecurity during the interview and from the use of a recorder, each experienced could be described with greater privacy.

\section{Theoretical-methodological reference}

This study is based on the phenomenology of Maurice MerleauPonty, allowing us to understand the man and the world from your "facticity" and from the perspective of the body being the only one able to give meaning to the world. From the experienced body, all the experience and the wisdom in the world can be revealed by perception ${ }^{(5)}$. This concept, when associated with research on school health, arises from relationships based on intentionality with the other.

The phenomenology studies the fundamental aspects of it. According to Maurice Merleau-Ponty, it occurs in direct experiences, where the perceptive act emerges from the meeting and imbrication between subject and object, what is expected from the relationship between student and health. The philosopher considers the human being as a sphere of meanings that undergo materialization and humanization in the encounter with the other ${ }^{(5)}$.

\section{Study type}

This is a descriptive study of qualitative approach, supported by the phenomenology of Maurice Merleau-Ponty to gather the experiences of students and expand the perception field, desires and needs of human beings on the matter, which contributes to a more complete and complex health practice. A COREQ 
(Consolidated Reporting Criteria for Qualitative Research) guideline was used to guide the writing of this article.

\section{Methodological procedures}

Data collection happened from March and April 2015, after a initial period of bonding between the researcher and the research participants. In the first month, the medical professional/academic researcher attended one of the two weekly high school physical education classes in the school to present herself as a medical professional and meet with the possible study participants and invite them to complete the survey. Given this face-to-face approach movement as part of the recruitment process, by the end of the first school month, the health professional/researcher invited students to participate in the study, by clarifying its objectives, the importance of their participation and the two available ways of report collection: the interview, to be scheduled according to the participant's preference on time and place, and the written answer to the guiding question, later inserted into a one of the three urns distributed over the collective spaces of the campus: health space, library and school yard/photocopy service.

After the formalized consent of adolescents who had already came of age, we carried out report gathering depending on the adolescent's report instrument of choice. Underage students who expressed interest received the terms of consent and had the contact number of their parents/legal guardians written down. The researcher called each parent/legal guardian, clarifying the objectives of the research and explaining importance of the participation of their children given the information provided in the sent documents. After receiving the authorization for under age students to participate in the research, the researcher sent a copy of the signed term to the parents/legal guardians and data collection proceeded according to the chosen collection instrument.

The recruitment was not performed in the graduation classes. However, some graduation students, intrigued by the presence of urns looked for the researcher to know if they could also participate in the research - some of them having contributed to it.

We opted for including students who have had attended the school health unit at least one time in our study, which we believe has had contributed to the gathering of different perspectives on the studied phenomenon. We excluded the written and spoken reports whose content did not meet the proposed objective.

\section{The study scenario}

The study was carried out in a federal public school in a city in the State of Rio de Janeiro, Brazil. Our reason for opting for this institution was that it offered integrated technical education to high school in agriculture, agribusiness, information technology, environment and chemistry fields, in addition to the course in food science and technology. In the way we see it, this is a representative environment, because it receives students from Northwest of Rio de Janeiro, Minas Gerais and from the state of Espírito Santo.

Opened in 1970 as agricultural technical school under municipal administration, the school was later linked to the UFF in 1974, becoming the campus of the Instituto Federal Fluminense by 2009 as a subordinate of the rectory of Campos dos Goytacazes - RJ.
Currently, its operating period extends from 7 to $10 \mathrm{pm}$. It has 18 classes of high school technical courses distributed in two classes of first, second and third year for agricultural and agribusiness courses; a class for each year of high school for computing and environment courses and the first class of chemistry; subsequent and/or concomitant courses on agriculture, agro-industry, information technology and the environment that last upon a year and a half, and the first class of the course of computer maintenance and support; in the mode of long-distance learning, there is the work safety technician course (a second year and a fourth year class), events technician and technician in multimedia teaching of the Pro-Staff Program, both with a class in the first module. In the third shift, the classes of the food science and technology take place, with classes of first, third, fifth and seventh periods. Accounting for 1,111 students distributed in 35 classes, the school offers accommodation for male students, who are selected according to family income and distance from home.

Despite not being linked to the Programa Saúde Na Escola, from the Brazilian Federal Government, it has its own health unit composed by a doctor (researcher of this study), a nursing assistant and an odontologist. The actions developed by the unit comprise primary health care activities, offering medical care service to students and campus staff. In an emergency and/or medical emergency, the patient is transferred to a hospital of the city by ambulance. For being involved in the process and for questioning this routine, the researcher designed this study to unveil the health service at the school by listening to what adolescents inserted in its cultural context have to say about it We believe this might contribute to the reorganization of the way school health works.

\section{Data source}

The interviews took place in the office number three or in the physical education room, depending on the student's preference; the manuscripts were collected in three urns, which were distributed over the reception of the health area, in the library and in the school yard next to the photocopy service, respectively.

From a total of 511 recruited high school students, 410 refused to participate in the research without clarifying the reasons for it, and data collection occurred with 101 students: A total of 34 attended the interview and 67 have put his manuscripts in the urns. From all the assessed manuscripts, 11 were excluded for not answering to the guiding question; and only 56 met the proposed objective. All interviews focused on the answering of the guiding question. Considering all the interviews and the 56 manuscripts, we gathered a total of 90 reports for analysis. From the interviewed ones, 14 were boys and 20 were girls, aged between 15 and 20 years. All of them attended a high school course integrated to the a technical course, 17 of them being from the agriculture field, one from the computing field, eight from environment and eight from agribusiness fields. Participants who opted for inserting their reports in the urns were classified based on schooling years. Five were from the first year of high school, 11 from the second, 13 from the third and three of them attended the graduation course; the other 24 did not provide this information in their manuscripts. During the research, no participants have quit from the study. 


\section{Collection and organization of data}

The recruitment process worked as an approximation strategy, during which the medical professional/researcher invited students to participate in the research by explaining the relevance and the objectives of the study proposal. Adolescents who had already came of age signed the ICF; underage adolescents had to present the ICF signed by their parents/legal guardians responsible and signed the FCCT. After formalizing consent, data collection proceeded based on the participant's choice (interview or written answer to the question guiding).

We aimed at understanding the perception of adolescents on school health to subsidize the care process of adolescents in the school setting, by listening to the students' prior experiences. Students who have chosen to participate of the interview, in a place of their preference, answered to the question: "Tell me what your perception on school health". After asking the question, the student was free to express their perception on the matter and to describe how they understand school health by using their own words. Those who wished to participate in the research, but found themselves shy and/or embarrassed, were given the option to deliver a manuscript to answer to the guiding question, which was written in the urn: "What do you know about health in school?" The written answer to the question aimed to capture the experience of the individual through the dynamics of understanding by revealing the experience behind it through descriptions, and preserving the anonymity of the author.

We did not recruit students of graduation courses, but those who showed interest could take part in the study after signing the written informed consent form.

The search did not precede pilot testing. There was no need to repeat the interviews. The data were recorded in a digital recorder. The duration of meetings were of 16 minutes in average. The stopped collecting data when the researcher noticed the data repetition, which featured saturation. The transcribed data were not handed out to participants at the end of the meeting.

\section{Analysis of the data}

Data were analyzed according to the phenomenology of Maurice Merleau-Ponty by following three major steps: the description of the phenomenon, phenomenological reduction and understanding ${ }^{(14)}$. The description implies the unveiling of the phenomenon experienced through transcribed language to undergo appreciation, signification and comprehension. Initially, reports and manuscripts were transcribed, read and re-read to allow us to understand the experience behind them and subsequently carry out its reduction. To the philosopher, reduction is when a contact originated in the world when describing their "own things", in the search for a primary meaning, an essential meaning to the lived experience ${ }^{(5)}$.

Simultaneously to the phenomenological comprehension, we carried out data interpretation to understand the core of the phenomenon described and to reduce it by intentional consciousness as a union of meanings, which does not suffer from variations manifested in data ${ }^{(5)}$, creating clusters in the following sub-topics: the "the school life world" - meeting and interacting with each other; the body - needs and ambiguities; the thinking body - attitudes assigned by words in the light of objective causality; the adolescent as a participant who speaks from experience.

\section{RESULTS}

\section{"The school life world": meeting and interacting with the other}

For adolescents, school health develops from harmonic relations between the self and the other to promote collective actions and healthy skills:

Living well with everyone around you. (U3)

Having a good communion with everyone, treating everyone the same way. Be healthy with everyone. (U3)

That's when people do their part happily, this way helping everyone. (U2)

It is how students engage in physical activity and interact with colleagues: it's a social bond. (U2)

School health help everyone to [...] achieve a satisfactory development, without experiencing physical and mental health problems. (U2)

It involves the collective. (U3)

\section{Body: needs and ambiguities}

The body is the vehicle of self in the world, it produces and integrates the significations of the environment of which is part ${ }^{(5)}$. The experienced "world of school life", sometimes unknown, generates feelings that oscillate between satisfaction, discomfort and conflict, characterized by the disharmony between health and education lived by the students. For adolescents, the school is seen as a second home, a place of belonging, coexistence and bonding, where they spend most of their day; however, the lack of information on the health service provided by the school, as well as by the level of commitment of health professionals involved, or by the lack of professionals available at all times and the lack of therapeutic inputs might threaten both individual and collective welfare:

I don't know much about it [...], I know that we were supposed to have something here. (A1)

It is something that should be more disseminated [...] many students don't even know there is a health clinic here. (A17)

Something that needs to become a priority, to receive more attention and expand its service, but our institution does not meet these requirements. (U1)

Health care needs more attention, because there have been several incidents and there was no one to help. (U2) 
On this campus, it is shameful. People have to choose the right day to get sick, because we don't have a doctor everyday and there is no medicine in any day. (U2)

We had this sport event at the campus [...] and my friend [...] fell. She got hurt, [...] needed medical service and we just had a nurse there, [...] and she seemed indifferent. (A23)

Whenever I come here I am well taken care of. (A3)

We arrive here at 7 in the morning and remain here to up until 16:30 and [...] if we feel sick we have the health clinic [...], the doctor we have there gives us some medicine for us to feel better. (A13)

My colleagues who have felt bad were well taken care of. (A28)

Most of our life we spend in school and what we have truly have is the school. Here we have a health clinic, and when you feel sick, they take care of you and if [...] they believe you need to be referred to the hospital, an ambulance comes to pick you up. (A30)

To provide a good health service for everyone should be a general concern. (A21)

We stay at school all day long, if we feel bad school health means having access to a prepared health professional to take care of us. (A16)

You say you're concerned with health, but [...] there's a lot more that you could do to help so that people wouldn't need to be taken to the hospital. (A18)

The ambulance [...] people who end up feeling really bad are referred to the hospital by ambulance. (A10)

They only have dipyrone. The clinic needed to provide a different medication for people to get better [...]. So there is need to raise the range of medications. (A31)

People say that sometimes they come here and the clinic does not have the medications to provide them. (A24)

The health clinic shouldn't even exist. If you feel bad, there's no point in coming here, because they only give you a piece of paper for you to buy your own medication [...], you have to deal with this by yourself. (A19)

We might gt bitten by a bug, or something like that [...] and at the clinic they they say you only need to put on some ice and you were ready to go! [...] We should have medications at our disposal. (A4)

Students must be willing to wait for an ambulance because of a simple headache because the school has no medication. (U2)

It's terrible when we go to the clinic looking for medication we could take for pain but they can't even provide us with that because the doctor is not even there. (U2)

School health is a complicate thing, because when you go to the health clinic feeling bad, they don't give you medicine" (U2)
Adolescents recognize that school health is impaired by the lack cleanliness of spaces of collective use. The surrounding is the center of juvenile concern, as the space is the mean by which health becomes possible:

The school has some dusty places like the sports court, the library and the kitchen balcony. Which is harmful for students who have respiratory problems. (U2)

Health is not only physical well being, it should also consider hygiene. [...] the sports court is always very dirty. This also concerns health [...]. Toilets sometimes lack soap, paper towels. (A14)

A ventilated, clean and organized space that makes people willing to stay. Ex: the library is hot/stuffy and unhealthy. (U2)

Air conditioning in the library. (U2)

It is cleanliness [...]. I thought the cleaning was very good, because it contributes to health. (A20)

According to Merleau-Ponty, the body is a being of ambiguity ${ }^{(15)}$. A statement that corroborates with adolescents' reports, which at times express nutritional concern over the menu they have at school, at times express satisfaction with the provided service:

The food is very precarious, we have heavy, greasy food here. [...] which end up making us feel sick during the day! (A27)

Whenever I eat a snack at school, I feel sick afterwards, because of the school's yogurt, because I think it has too many fat on it. Which makes us feel sick. (A9)

They're not so concerned with our food. (A5)

The food that we eat is very greasy. [...] / think they put too much oil on it. (A22)

It is great, because the food here is standardized. (U2)

The food staff wears gloves, always washes the food items very well. (A2)

\section{Thinking body: attitudes assigned by words in the light of objective causality}

The body is a thinking subject and the language is the exterior follow-up of thought, whose words emanate meanings and meanings lead to actions ${ }^{(5)}$. Adolescents, eager for knowledge, show interest in health education to understand it beyond common sense:

I don't know [...] maybe a project to raise awareness on the matter, we're young, there's lots of things to talk about, such as teen pregnancy, diseases. (A33)

It is important to offer students who have less access to information them the chance of asking questions about it when they find it necessary. (A32) 
We need to receive more support, [...] to address health education. (A8)

Which would help us to avoid young people to become misinformed adults. (U2)

We should adopt the AIDS week. (U3)

We needed to work on disease prevention, promoting lectures, symposium, campaigns. (U2)

We should have an AIDS prevention campaign. (U3)

To have health in school we need to have more lectures about it. (U2)

School health can help by clarifying doubts about things people don't feel comfortable to ask anyone. (U1)

Healthy food and habits, availability of medication, medical follow-up and lectures addressing health. (U2)

\section{The adolescent as a participant who speaks from experience}

Despite showing to be uncertain at times, adolescents have expressed the need for the school to meet all the demands regarding health by addressing their needs and weaknesses:

It is something necessary, especially in a full-time school. There is also need to provide this service to people who can't afford it outside the school environment. (U1)

I think [...] it is very important, [...] we stay 8 hours a day in the federal institution [...] we can't afford this service outside the school [...]. Many people [...] live here and if something happens, the school is the one hold accountable. (A11)

It is important to have doctors and nurses that they can help us and to have medication available so that we can get better when we're not feeling well. (U3)

It can help people who have no conditions to afford it. Considering we stay at school from 7 a.m to 16:30, we have the chance to go to the doctor, or attend a medical consultation. (A6)

To offer health care to the students at all times. (U1)

School health is something that needs to be well administered, dealt with responsibly and that considers all the students' needs. (U1)

To offer assistance to students who get sick while in school. (U3)

It stems from the precise observation of the students' health conditions in the school environment. (U2)

To take care of the students. (U3)

Some assistance [...]. (U3)

It assists students who get sick during the school year. (U3)

It is of paramount necessity [...] having a health service at school,
[...] we spend most of our day here and [...] we don't receive [...] this kind of support [...] from other areas (U1).

It's good, because if you get sick, a health professional will take care of you. (U1)

In emergencies [...] or even in cases when people don't feel very well: medication and assistance. (U1)

It is important to carry out student follow-up [...] because unforeseen events might happen. (U1)

In case any complications, students will receive the necessary care. (U1)

To have a doctor available at all times. And medication too. (U3)

To have doctors and medication available and good assistance. (U3)

Having doctors here at school, as many people here don't have easy access to medical consultations, to treatment and medical follow-up. (A12)

Having good nurses available to students who are not feeling well (U3)

Having a doctor to take care of us whenever necessary. (U3)

I think we need to have a doctor available at school during all school hours. (U3)

It is very important to offer students a place they can turn to when necessary. (U1)

It can help in a emergency. (U3)

We need to have medical care for the students who attend courses in the evening. (U2)

To have a doctor at school everyday (U3).

We need to have a doctor at school everyday! We never know when we might need one because we're feeling ill or because of an accident. (U2)

You should have a doctor at school [...] during all study periods and medications for all students. (U3)

Having a health professional available. (U2)

For when students need medical care and for when students might need to undergo medical exams. (U1)

I think it's important [...] because we could avoid having to go to the hospital whenever we don't feel well. (U1)

There is need for us to have quality assistance during all school periods. (U3)

Other adolescents, concerned with individual and collective school performance, showed interest in having psychological assistance, understood as a prerequisite to common welfare: 
Eh! [...] Many students go through problems at home, [...] families don't encourage them to take care of themselves and they end up having low school performance and [...] they need psychological assistance [...]. (A29)

I think it would be very nice, specially having psychological assistance, because students might not only suffer from physical problems, but also from mental illness. (A8)

Health comprises many aspects such as autonomy and physical, mental and collective well-being, which can interact thanks to body organization. Adolescents see physical education classes as their chance to conduct health practice to develop both physical skills and work on their self-esteem, in addition to food and hygienic conditions.

The physical part, in physical education [...] the teacher [...] demands our best, wants us to achieve our limits. (A26)

Having a healthy diet, practicing sports at school. (A25)

We can practice sports during our physical education classes. (A15)

Having a good diet. (U3)

It is maintaining hygiene and having healthy eating habits. (U1)

Healthy students, good nutrition, good hygiene. (U3)

Healthier food provision, the practice of physical exercises, [...] health control [...]. (A34)

\section{DISCUSSION}

The meaning of the school health experience according to adolescents corroborates to what Merleau-Pontian Phenomenology regarding the understanding of a phenomenon (school health experience) goes beyond subjectivity, comprising the interaction of the adolescent in the experienced "school life world". It is about describing the space, the time, the world we experience as it is ${ }^{(5)}$. One can apprehend this interaction between the man and the world by the meanings and significations, issued by written and spoken words and the particularities of each participant.

The adolescent's experiences regarding school health resemble the anthropocentric vision between health and environment, a hygienist perspective aimed at human health ${ }^{(16)}$. This balanced and harmonious environment is prerequisite for the survival of all organisms in an ecosystem. According to Minayo ${ }^{(17)}$, there is a strong interaction between the components of the ecosystem and well-being, affecting individual, collective and universal health. There is need to consider the connection between health, environment and society when discussing public health.

By analyzing the adolescents' reports, we noticed that many of them have characterized the phenomenon by using hygienist arguments. Students showed a mixture of emotions that ranged from satisfaction, anxiety and discontent with the care given and the therapeutic arsenal available, finding support in current health policies and biomedical model. They also revealed concerns over the cleanliness of the school - library, sports court, toilets - and the nutritional character of the food menu. Hygiene and balanced diet are one of the items that feature school health in a way that its non-compliance might lead to illness ${ }^{(16)}$.

In the context of school health, we observed that the way people perceive care and health is based on the hegemonic model without clarification of its strategic and political purposes, which leads the school health practice in Latin American countries in last two decades of the twentieth century ${ }^{(17-18)}$. This paradigm underwent a change of perspective based on the strategy of the Latin American Network of Health Promoting Schools, at the School Health Conference in Chile, in 1995. This model of health care at school, in response to the Pan American Health Organization's orientations (PAHO), has guided the building of public health policies addressing the school environment in Latin American and Caribbean countries. This model has three main pillars: health education; elaboration and maintenance of a harmonious and healthy environment; and provision of health services, healthy nutrition and well-being ${ }^{(19)}$. A school research on depression among adolescents highlighted these guidelines, where Fröjd et al. show that a multidisciplinary articulated work between health, education and society is an alternative model of care given to depressed adolescents ${ }^{(20)}$.

In Latin America, public policies that address school health comprise national and municipal initiatives associated with the implementation of health promotion strategies in schools and other concerns such as nutrition, weight control, oral health, ophthalmic care, dengue prevention and control, prevention of the use of alcohol, tobacco and other drugs, and sexual and reproductive health ${ }^{(18)}$. At first Brazilian schools thought about school health from the School Health Program [Programa Saúde na Escola], later reformed to improve the quality of life in the communities of municipal and state schools ${ }^{(21)}$. Despite its recent changes, the implementation of programs and projects do not disregard the traditional standards, i.e. having proper resources to comply with school health practice competes with the actions supported by hygienist ideas ${ }^{(18)}$.

In this implementation process, human reluctance to change represents one of the most notorious obstacles among many others, being responsible for the health care given to adolescents. The adolescent understands the school environment as a place where they can find assistance and that ensures individual and collective well-being, despite basing their actions on the hygienist's perspective. Adolescents' reports mention aspirations such as health care provision during all school periods, the participation of doctors, availability of nursing and psychology professionals to provide physical and mental care to students, and the use of medications as a necessary therapeutic inputs, whose lack might contribute to the emergence of diseases, also leading to falls in school performance, and school evasion.

Paradoxically, reports show school health focused on health promotion, highlight the practice of physical activity - essential to prevent and control cardiovascular diseases, and consumptive and metabolic syndromes - and the consolidation of healthy habits ${ }^{(22-23)}$. Abildsnes et al. claim that quality physical education programs are facilitators in the adoption of a healthy lifestyle among adolescents and that nurses noticed a growing demand for school health services to carry out the follow-up of students who dropout from physical education classes $^{(24)}$. 
Adolescents associate school health with popular health education initiatives such as awareness campaigns aimed at fostering habits and healthy behaviors and carrying out health interventions - experience observed by a Swedish study on adolescents' experience on oral health action conducted in two Swedish secondary schools for two years ${ }^{(25)}$. This perceived ambiguity does not imply imperfection, but a dynamic perception that considers other corresponding elements and stunts of various meanings in the idea exchanging process. According to Merleau-Ponty, the body has its own needs and ambiguities, without distinction between the parties, i.e. they complement each other ${ }^{(15)}$.

The effectiveness of school health promotion actions leads itself to participatory action, from the consolidation of links with the educational community aimed at achieving completeness of care depending on the socio-cultural context. Therefore, we recommend the qualification of health professionals in intersectoral activities and the establishment of partnerships with teachers. The teacher multiplies and transforms knowledge. The health care professional, particularly doctors and nurses, can guide the training of other professionals on the health concepts, according to the international conventions and public policies ${ }^{(18)}$.

School health is an intersectoral and interdisciplinary strategy aimed at improving individual and collective skills in a dynamic and preventive way to achieve a equity regarding quality of life at school. School health promotion requires a more complex mobilization than the one we have in the health sector as it involves managers, the community itself and collaborative actions from the public sector, non-governmental and private organizations ${ }^{(26)}$.

The implications of this study in school health practice are complex, as they consider the attentive listening of the adolescentsubject, now understood from their experience with the "school life world". The health care professional guides the care process, bonding with teachers and professors to share knowledge and expertise, thus aligning adolescents' actions to the their life plan and health project ${ }^{(27)}$.

\section{Study limitations}

Our sample only comprised a group of adolescents of a certain school of the federal network of the State of Rio de Janeiro, Brazil. Although the findings revealed the meaning and significations assigned by students on school health, their reports only address the particularities of this research context. To expand the evidences, there is need for further studies approaching different contexts, which, together with the knowledge obtained in this study, could foster the elaboration of public policies focused on adolescents at school.

\section{Contributions to the public health and nursing fields}

The knowledge obtained in this study provides relevant information that can guide the school health approach, by basing on what students have to say, not taking for granted the student protagonism regarding their own health, and by mainly considering care as a whole and the socio-cultural demands raised. We highlight the role of the health professional, which works as an advisor and mediator in the process of developing skills and delegating responsibilities to managers, teachers and the community aiming at facilitating the provision and multiplication of care.

In academic terms, this research might contribute to discussions on nursing formation and other health areas. Students of undergraduate and postgraduate courses could also acquire skills to provide appropriate care to adolescents, which include professional domain, care based on solidarity, dedication and social responsibility aimed at achieving equity, completeness and uniqueness of care, all pillars of the Brazilian Unified health system (SUS).

\section{FINAL CONSIDERATIONS}

Understanding adolescents' perception on school health contributed to the valorization of subject's experience in "school life world" according to Merleau-Pontian existential phenomenology.

In the experience of school health, anthropocentrism predominates - the man at the center and the surroundings as a facilitator of their care - , permeated by hygienist actions focused on biomedical model, which by disregarding such practice, contributes to the sickening and the weakening of the school community.

Additionally, we also highlight the influence of health promotion actions based on the practice of physical activity and popular health education over the reorganization of school health; the health care professional is the one that transforms reality by articulating management, teaching and school community to produce and expand knowledge on care practice.

The school is a suitable environment for health practice considering the active participation of its peers. This study corroborates with the idea that school health by diving into the adolescent's "school life world", by understanding the meanings and significations of each generation to contribute to public policy development focused on adolescent health.

\section{FUNDING}

The publication of this study received financial support from Fundação Carlos Chagas Filho de Amparo à Pesquisa do Estado do Rio de Janeiro (Faperj).

\section{REFERENCES}

1. Bouzas I, Jannuzzi F. Children's and Adolescents'Statute (ECA): 25 years. Adolesc Saude [Internet]. 2015 [cited 2018 Jun 3];12(2):6. Available from: http://www.adolescenciaesaude.com/detalhe_artigo.asp?id=496

2. Instituto Brasileiro de Geografia e Estatística; Coordenação de Trabalho e Rendimento. Pesquisa Nacional por Amostra de Domicílios: Síntese de Indicadores 2015. Rio de Janeiro: IBGE; 2016.

3. Faial LCM, Silva RMCRA, Pereira ER, Souza LMC, Faial CSG, Cadengo ESN. Vulnerability in adolescents: a timely area for the practice of health: integrative review. Rev Enferm UFPE. 2016;10(9):3473-82. doi: 10.5205/reuol.9571-83638-1-SM1009201636 
4. Almeida TCS. Espiritualidade e resiliência: enfrentamento em situações de luto. Sacrilegens [Internet]. 2015 [cited 2018 Sep 29];12(1):72-91. Available from: http://www.uff..br/sacrilegens/files/2016/03/12-1-7.pdf

5. Merleau-Ponty M. Fenomenologia da percepção. 4th ed. São Paulo: WMF Martins Fontes; 2011.

6. Knoll LJ, Magis-Weinberg L, Speekenbrink M, Blakemore S-J. Social influence on risk perception during adolescence. Psychol Sci. 2015;26(5):583-92. doi: 10.1177/0956797615569578

7. Faial LCM, Silva RMCRA, Pereira ER, Refrande SM, Faial CSG. A escola como campo de promoção à saúde na adolescência: revisão literária. Rev Pró-Uni [Internet]. 2016 [cited 2018 Jun 3];7(2):22-9. Available from: http://editorauss.uss.br/index.php/RPU/article/view/344

8. Currie C, Gabhainn SN, Godeau E, Roberts C, Smith R, Currie D, et al., ed. Inequalities in young people's health: Health Behaviour in SchoolAged Children International Report from the 2005/2006 Survey. Copenhagen: World Health Organization; 2008. 206 p. (Health Policy for Children and Adolescents, no. 5)

9. Global School-Based Student Health Survey (GSHS) [Internet]. Copenhagen: World Health Organization; 2013 [cited 2018 Sep 29]. Available from: http://www.who.int/ncds/surveillance/gshs/en/

10. Kann L, McManus T, Harris WA, Shanklin SL, Flint KH, Hawkins J, et al. Youth Risk Behavior Surveillance - United States, 2015. MMWR Surveill Summ. 2016;65(6):1-174. doi: 10.15585/mmwr.ss6506a1

11. Oliveira MM, Campos MO, Andreazzi MAR, Malta DC. Characteristics of the National Adolescent School-based Health Survey - PeNSE, Brazil. Epidemiol Serv Saúde. 2017;26(3):605-16. doi: 10.5123/S1679-49742017000300017

12. Biblioteca Virtual em Saúde. DeCS Server - List Exact Term [Internet]. [date uknown] [cited 2018 Jul 23]. Available from: http://decs.bvs.br/cgi-bin/wxis1660.exe/decsserver/?IsisScript=../cgi-bin/decsserver/decsserver. xis\&interface_language $=p \&$ previous_page $=$ homepage\&previous_task=NULL\&task=start

13. Conselho Nacional de Saúde (BR). Resolução n 466, de 12 de dezembro de 2012. Diário Oficial da União [Internet]. 2013 Jun 13 [cited 2018 Jun 4];1:59. Available from: http://conselho.saude.gov.br/resolucoes/2012/Reso466.pdf

14. Giorgi A. The phenomenological movement and research in the human sciences. Nurs Sci Q [Internet]. 2005 [cited 2018 Jun 5];18(1):75-82. Available from: http://journals.sagepub.com/doi/10.1177/0894318404272112

15. Falabretti E. Merleau-Ponty e Marion: o problema da ambiguidade entre uma fenomenologia da percepção e uma fenomenologia da doação. Rev Fil Mod Contemp [Internet]. 2015 [cited 2018 Jun 3];3(2):87-102. Available from: http://periodicos.unb.br/index.php/fmc/ article/view/12514/10929

16. Fonseca AFQ. Ambiente e saúde: visão de profissionais da saúde da família. Ambient Soc [Internet]. 2012 [cited 2018 Jun 3];15(2):133-50. Available from: http://www.scielo.br/pdf/asoc/v15n2/08.pdf

17. Minayo MCS. O desafio do conhecimento: pesquisa qualitativa em saúde. 14th ed. São Paulo: Hucitec; 2014.

18. Casemiro JP, Fonseca ABC, Secco FVM. Promover saúde na escola: reflexões a partir de uma revisão sobre saúde escolar na América Latina. Ciênc Saúde Coletiva. 2014;19(3):829-40. doi: 10.1590/1413-81232014193.00442013

19. Mont'Alverne DGB, Catrib AMF. Health promotion and schools: how to move forward. Rev Bras Promoc Saude [Internet]. 2013 [cited 2018 Jun 2];26(3):307-8. Available from: http://periodicos.unifor.br/RBPS/article/view/2924

20. Fröjd S, Marttunen M, Pelkonen M, von der Pahlen B, Kaltiala-Heino R. Adult and peer involvement in help-seeking for depression in adolescent population. Soc Psychiat Epidemiol. 2007;42(12):945-52. doi: 10.1007/s00127-007-0254-4

21. Ministério da Educação (BR); Ministério da Saúde (BR). Portaria Interministerial no 1.055 de 25 de abril de 2017. Diário Oficial da União [Internet]. 2017 Apr 26 [cited 2018 Jun 2];1:36. Available from: http://bvsms.saude.gov.br/bvs/saudelegis/gm/2017/pri1055_26_04_2017.html

22. Faial LCM, Silva RMCRA, Pereira ER, Faial CSG, Deus VAH. Perceptions of adolescents on health at school in the light of a Merleaupontian phenomenology. Rev Min Enferm. 2018;22:e-1136. doi: 10.5935/1415-2762.20180065

23. Silva KVLG, Gonçalves GAA, Santos SB, Machado MFAS, Rebouças CBA, Silva VM, et al. Training of adolescent multipliers from the perspective of health promotion core competencies. Rev Bras Enferm [Internet]. 2018;71(1):89-96. doi: 10.1590/0034-7167-2016-0532

24. Abildsnes E, Stea TH, Berntsen S, Omfjord CS, Rohde G. Physical education teachers' and public health nurses' perception of Norwegian high school students' participation in physical education: a focus group study. BMC Public Health [Internet]. 2015 [cited 2018 Jul 25];15(1):1295. Available from: doi: 10.1186/s12889-015-2660-y

25. Hedman E, Gabre P, Birkhed D, Lepp M. Adolescents' experiences of a two-year oral health intervention programme in two Swedish secondary schools. Int J Dent Hygiene. 2013;11(4):244-52. doi: 10.1111/idh.12035

26. Reis AAC, Malta DC, Furtado LAC. Challenges for public policies aimed at adolescence and youth based on the National Scholar Health Survey (PeNSE). Ciênc Saúde Coletiva. 2018;23(9):2879-90. doi: 10.1590/1413-81232018239.14432018

27. Faial LCM, Silva RMCRA, Pereira ER, Souza LMC, Bessa RT, Faial CSG. Health at school: phenomenological contributions from the teacher's perception. Rev Enferm UFPE On Line. 2016;11(1):24-30. doi: 10.5205/reuol.9978-88449-6-1101201704 